\title{
Sphingobium scionense sp. nov., an aromatic hydrocarbon-degrading bacterium isolated from contaminated sawmill soil
}

\author{
Quanfeng Liang ${ }^{1,2}$ and Gareth Lloyd-Jones ${ }^{1}$ \\ ${ }^{1}$ Scion, Te Papa Tipu Innovation Park, Private Bag 3020, Rotorua, New Zealand \\ ${ }^{2}$ State Key Laboratory of Microbial Technology, National Glycoengineering Research Center, \\ Shandong University, Jinan, Shandong 250100, PR China
}

Correspondence

Gareth Lloyd-Jones

gareth.lloyd-jones@

scionresearch.com
Amongst the sphingomonads, many strains have been described that are able to degrade different aromatic hydrocarbons, including naphthalene and biphenyls (Lloyd-Jones \& Lau, 1997; Pinyakong et al., 2003; Leys et al., 2004). Biphenyls and naphthalene represent two important classes of environmental pollutants, the polychlorinated biphenyls (PCBs) and polycyclic aromatic hydrocarbons (PAHs). Strain $\mathrm{WP}^{\mathrm{T}} 1^{\mathrm{T}}$ was isolated previously from contaminated soil containing oil residues and Pinus radiata sap and sawdust and, prior to the division of the genus Sphingomonas by Takeuchi et al. (2001), had been tentatively identified as belonging to the genus Sphingomonas (Lloyd-Jones \& Lau, 1997). In this study, a taxonomic reevaluation of strain $\mathrm{WP}^{\mathrm{T}} \mathrm{I}^{\mathrm{T}}$ indicated that this strain should be regarded as a member of the genus Sphingobium.

The genus Sphingomonas was described by Yabuuchi et al. (1990) as comprising strictly aerobic, chemoheterotrophic, yellow-pigmented, Gram-negative, rod-shaped bacteria that

Abbreviation: $\mathrm{PHA}$, polyhydroxyalkanoate.

The GenBank/EMBL/DDBJ accession number for the 16S rRNA gene sequence of strain WPO1 ${ }^{\top}$ is EU009209. contain glycosphingolipids as cell-envelope components. Takeuchi et al. (1994) described four phylogenetic clusters in the genus, based on $16 \mathrm{~S}$ rRNA gene sequence data, and subsequently combined phylogenetic, chemotaxonomic and physiological analyses to divide the genus into four genera: Sphingomonas, Sphingobium, Novosphingobium and Sphingopyxis (Takeuchi et al., 2001). Recently, the genus Sphingosinicella (Maruyama et al., 2006) has been added to the family Sphingomonadaceae. Here, we report on the classification of strain $\mathrm{WP} 1^{\mathrm{T}}$ as a novel member of the genus Sphingobium. The type species of this ever-expanding genus is Sphingobium yanoikuyae and species with validly published names include $S$. amiense (Ushiba et al., 2003), S. aromaticiconvertens (Wittich et al., 2007), S. chlorophenolicum (Takeuchi et al., 2001), S. chungbukense (Pal et al., 2005), S. cloacae (Prakash \& Lal, 2006), S. francense (Pal et al., 2005), S. fuliginis (Prakash \& Lal, 2006), S. herbicidovorans (Takeuchi et al., 2001), S. indicum (Pal et al., 2005), S. japonicum (Pal et al., 2005), S. olei (Young et al., 2007), S. xenophagum (Pal et al., 2006), S. yanoikuyae (Yabuuchi et al., 1990; Takeuchi et al., 2001), S. ummariense (Singh \& Lal, 2009) and S. rhizovicinum (Young et al., 2008). 
The bacterium designated $\mathrm{WP} 01^{\mathrm{T}}$ is an aerobic, non-sporeforming, non-motile, Gram-staining-negative rod that was originally isolated for its ability to degrade phenanthrene. It is also capable of degrading naphthalene, biphenyl, $\mathrm{m}$ xylene and benzoate (Lloyd-Jones \& Lau, 1997) in mineral salts medium (Lloyd-Jones et al., 1999). On nutrient agar (per litre: $3 \mathrm{~g}$ beef extract, $5 \mathrm{~g}$ peptone; Difco), yellow, round, convex and shiny colonies are formed, appearing within $2-4$ days at $30{ }^{\circ} \mathrm{C}$, which is the optimal temperature for growth. Strain $\mathrm{WP} 1^{\mathrm{T}}$ is also able to grow in LuriaBertani (LB) broth (per litre: $10 \mathrm{~g}$ tryptone, $5 \mathrm{~g}$ yeast extract, $10 \mathrm{~g} \mathrm{NaCl}$ ) and is able to tolerate $0.6 \mathrm{M} \mathrm{NaCl}$ in nutrient broth. Strain $\mathrm{WP} 01^{\mathrm{T}}$ is chemoheterotrophic and is able to assimilate the carboxylic acids malate, succinate, Dgluconate and benzoate, the carbohydrates L-arabinose, Dglucose, maltose, galactose, rhamnose and xylose, and the aromatic hydrocarbons $m$-xylene, biphenyl, naphthalene and phenanthrene. Biochemical characteristics (API 20 NE; bioMérieux) include a positive catalase reaction and the abilities to hydrolyse aesculin, to produce $\beta$-galactosidase and to reduce nitrate to nitrite. Compared with $S$. yanoikuyae JCM $7371^{\mathrm{T}}$, with which strain $\mathrm{WP} 01^{\mathrm{T}}$ shares a similar catabolic profile, the differences are the ability of strain $\mathrm{WP} 01^{\mathrm{T}}$ to reduce nitrate and its inability to utilize citrate (Table 1). The polyhydroxyalkanoate (PHA) content and composition in biomass were determined according to the method of Riis \& Mai (1988) and it was shown that strain $\mathrm{WP} 01^{\mathrm{T}}$ was able to accumulate the storage polymer PHA. The dominant ester formed by trans-esterification of the extracted PHA was propyl-3hydroxybutyrate (identity confirmed by GC-MS analysis and by comparison with authentic standards; $99.8 \pm 0.2 \%$ of the analysed esters), from which we concluded that strain $\mathrm{WP} 01^{\mathrm{T}}$ forms the aliphatic polymer poly- $\beta$-hydroxybutyrate, which, with $10 \mathrm{mM}$ glucose, is accumulated to comprise up to $24.1 \%$ of the cell-mass dry weight.

Table 1. Biochemical characteristics of strain $W P 01^{\top}$ and the type strains of $S$. amiense and $S$. yanoikuyae

Strains: 1 , $\mathrm{WP}_{01}^{\mathrm{T}}$; 2, S. amiense $\mathrm{YT}^{\mathrm{T}} ; 3$, S. yanoikuyae JCM $7371^{\mathrm{T}}$. All strains were positive for assimilation of D-glucose and maltose. All strains were negative for urease activity. Data for taxa 2 and 3 were taken from Ushiba et al. (2003).

\begin{tabular}{|lccc|}
\hline Characteristic & $\mathbf{1}$ & $\mathbf{2}$ & $\mathbf{3}$ \\
\hline Assimilation of: & & & \\
$\quad$ N-Acetyl-D-glucosamine & + & - & + \\
L-Arabinose & + & - & + \\
Citrate & - & - & + \\
Gluconate & + & - & + \\
Malate & + & - & + \\
D-Mannose & - & - & - \\
$\beta$-Galactosidase activity & + & - & + \\
Aesculin hydrolysis & + & - & + \\
Nitrate reduction & + & - & - \\
\hline
\end{tabular}

The cellular fatty acid composition was analysed in cells grown on trypticase soy agar at $28{ }^{\circ} \mathrm{C}$ for $24 \mathrm{~h}$ (MIDI). The major fatty acids of strain $\mathrm{WP} 01^{\mathrm{T}}$ were octadecenoic acid $\left(\mathrm{C}_{18: 1} \omega 7 c ; 56.0 \%\right)$, hexadecenoic acid $\left(\mathrm{C}_{16: 1} \omega 7 c ; 18.8 \%\right)$, hexadecanoic acid $\left(\mathrm{C}_{16: 0} ; 11.9 \%\right)$ and the hydroxy fatty acid 2-hydroxytetradecanoic acid $\left(\mathrm{C}_{14: 0} 2-\mathrm{OH} ; 9.0 \%\right)$. In addition, the following minor fatty acids were identified: $\mathrm{C}_{16: 1} \omega 5 c(1.7 \%), \mathrm{C}_{17: 1} \omega 7 c(0.6 \%), \mathrm{C}_{16: 0} 2-\mathrm{OH}(0.7 \%)$ and $\mathrm{C}_{18: 1} \omega 5 c(1.3 \%)$. The fatty acid profile of strain WP01 ${ }^{\mathrm{T}}$ contains $\mathrm{C}_{16: 0}, \mathrm{C}_{16: 1}, \mathrm{C}_{18: 1}$ and $\mathrm{C}_{14: 0} 2-\mathrm{OH}$ as the major fatty acids, which are characteristic of the genus Sphingobium (Busse et al., 1999; Yabuuchi et al., 1990, 2002; Takeuchi et al., 1995, 2001); however, the proportions were significantly different from those for cluster II: $\mathrm{C}_{18: 1} 56.0 \%$ versus $32 \%, \mathrm{C}_{16: 1} 18.8 \%$ versus $8 \%, \mathrm{C}_{16: 0}$ $11.9 \%$ versus $10 \%$ and $\mathrm{C}_{14: 0} 2-\mathrm{OH} 9.0 \%$ versus $34 \%$, for strain $\mathrm{WP}^{\mathrm{T}} 1^{\mathrm{T}}$ and cluster II respectively (Takeuchi et al., 2001).

Polar lipid and respiratory quinone analyses were carried out by the Identification Service of the DSMZ and Dr B. J. Tindall, DSMZ, Braunschweig, Germany. The dominant respiratory quinone was Q-10 (89\%), with lesser amounts of Q-9 (11\%). The polar lipid pattern predominately contained diphosphatidylglycerol, phosphatidylethanolamine, phosphatidylglycerol and sphingoglycolipid 1, with lesser amounts of sphingoglycolipid 2. Significantly smaller amounts of phosphatidylcholine and trace amounts of an unidentified aminophospholipid, which migrated close to the origin, were also present. Strain $\mathrm{WP} 01^{\mathrm{T}}$ contained the same major polar lipids as those found in S. yanoikuyae IFO $15102^{\mathrm{T}}$ (Busse et al., 1999); however, phosphatidyldimethylethanolamine and an unidentified glycolipid were absent.

Polyamines were extracted and analysed by HPLC as described by Takeuchi et al. (2001). The polyamine pattern of strain $\mathrm{WP} 01^{\mathrm{T}}$ had spermidine as the main polyamine (1.98 $\mu \mathrm{mol} \mathrm{g}^{-1}$ wet weight), but homospermidine and putrescine were absent. DNA base compositions were determined by thermal denaturation (Marmur \& Doty, 1962) using a spectrophotometer (DU800; Beckman) and the genomic DNA of Escherichia coli K-12 as the standard for the calibration of $T_{\mathrm{m}}$ values. The DNA G $+\mathrm{C}$ content of strain $\mathrm{WP} 01^{\mathrm{T}}$ was $63.8 \mathrm{~mol} \%$, which was in accordance with the range described for the genus Sphingobium (61.7$64.9 \mathrm{~mol} \%$ ) (Yabuuchi et al., 1990; Takeuchi et al., 1995, 2001).

An almost full-length 16S rRNA gene sequence from strain WP $01^{\mathrm{T}}$ was obtained as described by Rochelle et al. (1995). Analysis of this and other published sequences revealed that strain $\mathrm{WP} 01^{\mathrm{T}}$ was most similar to bacteria previously described as belonging to S. yanoikuyae. Strain $\mathrm{WP} 01^{\mathrm{T}}$ shared $98 \%$ 16S rRNA gene sequence similarity with sequences from the S. yanoikuyae strains Q1 (GenBank accession number U37525) and B1 (U37524.1), with which strain $\mathrm{WP} 01^{\mathrm{T}}$ also exhibited sequence similarity in the genes encoding the enzymes required for the catabolism of 
aromatic compounds (Lloyd-Jones \& Lau, 1997). The $16 \mathrm{~S}$ rRNA gene sequence of strain WP $01^{\mathrm{T}}$ had high sequence similarity values with sequences from the type strains of the genus Sphingobium, S. yanoikuyae GIFU $9882^{\mathrm{T}}$ and $S$. amiense $\mathrm{YT}^{\mathrm{T}}$ ( $97.31 \%$ and $97.16 \%$, respectively). The $16 \mathrm{~S}$ rRNA gene sequence from strain $\mathrm{WP} 01^{\mathrm{T}}$ retained the nucleotide signatures that correspond to cluster II (genus Sphingobium) as defined by Takeuchi et al. (2001): 52:359 U:A, $134 \mathrm{G}, 593 \mathrm{U}, 987: 1218 \mathrm{~A}: \mathrm{U}$ and 990:1215 U:G. Phylogenetic analysis was performed by comparison with 16S rRNA gene sequences from other type strains belonging to the genus Sphingobium. The sequences were aligned using the CLUSTAL_X algorithm over 1335 aligned positions and a phylogenetic tree was constructed using the maximum-likelihood algorithm with 1000 bootstrap analyses using DNAMAN version 5.2.2 (Lynnon Biosoft). The results (Fig. 1) showed that strain $\mathrm{WP} 01^{\mathrm{T}}$ is related to other species of the genus Sphingobium and is most closely related to S. yanoikuyae GIFU $9882^{\mathrm{T}}$ and S. amiense $\mathrm{YT}^{\mathrm{T}}$.

DNA-DNA hybridization was used to compare the similarity of strain $\mathrm{WP} 01^{\mathrm{T}}$ to its closest phylogenetic neighbours. Genomic DNA was extracted from strain WP $01^{\mathrm{T}}$ and S. yanoikuyae GIFU $9882^{\mathrm{T}}$ and purified according to the method of Marmur (1961) with an additional proteinase $\mathrm{K}$ digestion and SDS treatment. DNA-DNA hybridization was carried out according to the methods of De Ley et al. (1970) and Huß et al. (1983) using a Perkin Elmer Lambda 35 UV/VIS spectrometer equipped with a PTP-6 Peltier system. The DNA-DNA relatedness value between strain $\mathrm{WP}^{\mathrm{T}} 1^{\mathrm{T}}$ and $S$. yanoikuyae GIFU $9882^{\mathrm{T}}$ was $46.6 \%$, which falls below the value of approximately $70 \%$ that has been suggested as a threshold to delineate bacterial species (Grimont, 1999; Wayne et al., 1987). Additional DNA-DNA hybridization experiments between strain $\mathrm{WP}^{\mathrm{T}} 1^{\mathrm{T}}$ and $S$. amiense DSM $16289^{\mathrm{T}}$ were carried out by the identification service at DSMZ. The DNA-DNA relatedness value between strain $\mathrm{WP} 01^{\mathrm{T}}$ and $S$. amiense DSM $16289^{\mathrm{T}}$ was $25.6 \%$.
Strain $\mathrm{WP}^{\mathrm{T}}$ shares many characteristics of the genus Sphingobium (Takeuchi et al., 2001): it is strictly aerobic and catalase-positive, has Q10 as the predominant ubiquinone and $\mathrm{C}_{18: 1} \omega 7 c$ as the dominant fatty acid. The DNA $\mathrm{G}+\mathrm{C}$ content and $16 \mathrm{~S}$ rRNA gene nucleotide signatures are also consistent with the genus. The ability to reduce nitrate and the low DNA-DNA relatedness values with S. yanoikuyae GIFU $9882^{\mathrm{T}}$ and S. amiense DSM $16289^{\mathrm{T}}$ suggest that strain $\mathrm{WP} 01^{\mathrm{T}}$ should be considered as representing a novel species within the genus Sphingobium, for which the name Sphingobium scionense sp. nov. is proposed.

\section{Description of Sphingobium scionense sp. nov.}

Sphingobium scionense (sci.o.nen'se. N.L. neut. adj. scionense pertaining to Scion, a Crown Research Institute close to the isolation source of the type strain).

Cells are Gram-negative-staining, aerobic, non-sporeforming and non-motile rods measuring $0.5-0.6 \times 1.6-$ $2.0 \mu \mathrm{m}$ that produce yellow, round, convex and shiny colonies within $2-4$ days on nutrient agar at $30{ }^{\circ} \mathrm{C}$. Growth is observed at $15-35{ }^{\circ} \mathrm{C}$ (optimum $30{ }^{\circ} \mathrm{C}$ ) but not at $37{ }^{\circ} \mathrm{C}$. Accumulates polyhydroxyalkanoate granules in the form of poly- $\beta$-hydroxybutyrate from glucose and acetate. Positive for catalase and nitrate reductase. Negative for urease, oxidase and arginine dihydrogenase, indole production, acid production from glucose and assimilation of sorbitol, inositol, malonate, sucrose, lactose, adonitol and raffinose. The dominant fatty acids are $\mathrm{C}_{18: 1} \omega 7 c, \mathrm{C}_{16: 1} \omega 7 c$ and $\mathrm{C}_{16: 0}$ and the only hydroxy fatty acid is $\mathrm{C}_{14: 0} 2-\mathrm{OH}$. The dominant polar lipids are diphosphatidylglycerol, phosphatidylethanolamine, phosphatidylglycerol and sphingoglycolipid 1, with lesser amounts of sphingoglycolipid 2 . Spermidine is the main polyamine.

The type strain, $\mathrm{WP}_{01}^{\mathrm{T}}\left(=\mathrm{DSM} 19371^{\mathrm{T}}=\mathrm{ICMP} 13533^{\mathrm{T}}\right)$, was isolated from hydrocarbon-contaminated sawmill soil, New Zealand. The DNA G $+\mathrm{C}$ content of the type strain is $63.8 \mathrm{~mol} \%$.

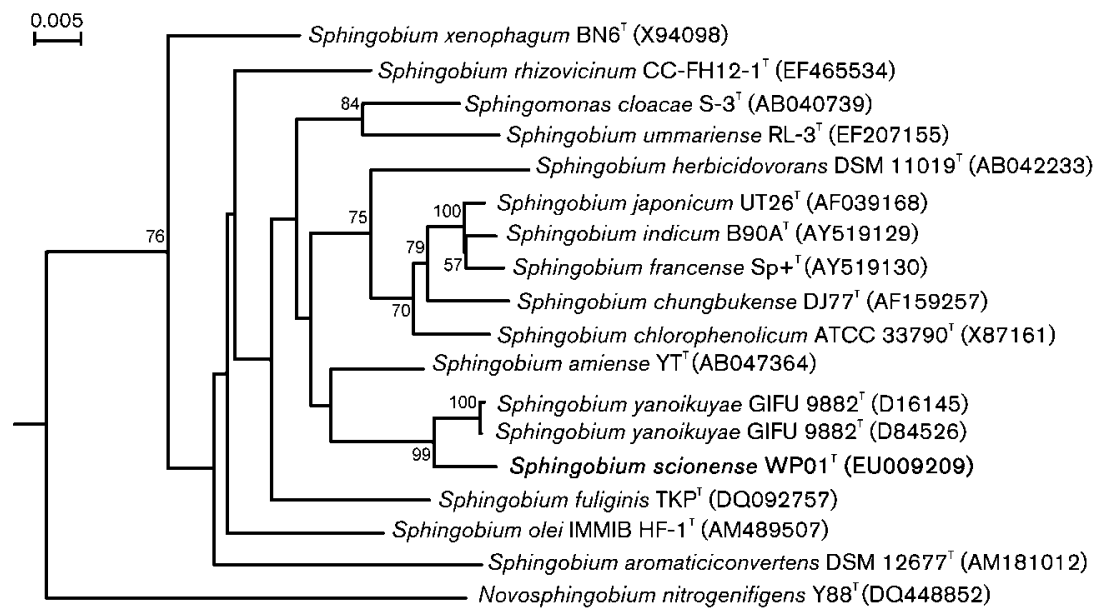

Fig. 1. Phylogenetic tree based on almostcomplete 16S rRNA gene sequences (1335 aligned positions) showing the relationship between strain WP01 ${ }^{\top}$ and type strains of species in the genus Sphingobium. The tree was constructed with the maximum-likelihood method. Bootstrap values ( $>50 \%$ ) based on 1000 replications are shown at branch nodes. Novosphingobium nitrogenifigens $\mathrm{Y} 88^{\top}$ was used as the outgroup. Bar, 0.005 substitutions per nucleotide position. 


\section{Acknowledgements}

This work was supported by the New Zealand Foundation for Research Science and Technology and by a Scion Postdoctoral Fellowship to Q. L. We thank Daniel van de Pas (Scion) for PHA analysis.

\section{References}

Addison, S. L., Foote, S. M., Reid, N. M. \& Lloyd-Jones, G. (2007). Novosphingobium nitrogenifigens sp. nov., a polyhydroxyalkanoateaccumulating diazotroph isolated from a New Zealand pulp and paper wastewater. Int J Syst Evol Microbiol 57, 2467-2471.

Busse, H.-J., Kämpfer, P. \& Denner, E. B. M. (1999). Chemotaxonomic characterisation of Sphingomonas. J Ind Microbiol Biotechnol 23, 242-251.

De Ley, J., Cattoir, H. \& Reynaerts, A. (1970). The quantitative measurement of DNA hybridization from renaturation rates. Eur $J$ Biochem 12, 133-142.

Grimont, P. A. D. (1999). Taxonomy and classification of bacteria. In Manual of Clinical Microbiology, 7th edn, pp. 249-259. Edited by P. R. Murray, E. J. Baron, M. A. Pfaller, F. C. Tenover \& R. H. Yolken. Washington, DC: American Society for Microbiology.

Huß, V. A. R., Festl, H. \& Schleifer, K. H. (1983). Studies on the spectrophotometric determination of DNA hybridization from renaturation rates. Syst Appl Microbiol 4, 184-192.

Leys, N. M., Ryngaert, A., Bastiaens, L., Verstraete, W., Top, E. M. \& Springael, D. (2004). Occurrence and phylogenetic diversity of Sphingomonas strains in sites contaminated with polycyclic aromatic hydrocarbons. Appl Environ Microbiol 70, 1944-1955.

Lloyd-Jones, G. \& Lau, P. C. (1997). Glutathione S-transferaseencoding gene as a potential probe for environmental bacterial isolates capable of degrading polycyclic aromatic hydrocarbons. Appl Environ Microbiol 63, 3286-3290.

Lloyd-Jones, G., Laurie, A. D., Hunter, D. W. F. \& Fraser, R. (1999). Analysis of catabolic genes for naphthalene and phenanthrene degradation in contaminated New Zealand soils. FEMS Microbiol Ecol 29, 69-79.

Marmur, J. (1961). A procedure for the isolation of deoxyribonucleic acid from microorganisms. J Mol Biol 3, 208-218.

Marmur, J. \& Doty, P. (1962). Determination of the base composition of deoxyribonucleic acid from thermal denaturation temperature. J Mol Biol 5, 109-118.

Maruyama, T., Park, H.-D., Ozawa, K., Tanaka, Y., Sumino, T., Hamana, K., Hiraishi, A. \& Kato, K. (2006). Sphingosinicella microcystinivorans gen. nov., sp. nov., a microcystin-degrading bacterium. Int J Syst Evol Microbiol 56, 85-89.

Pal, R., Bala, S., Dadhwal, M., Kumar, M., Dhingra, G., Prakash, O., Prabagaran, S. R., Shivaji, S., Cullum, J. \& other authors (2005). Hexachlorocyclohexane-degrading bacterial strains Sphingomonas paucimobilis B90A, UT26 and $\mathrm{Sp}+$, having similar lin genes, represent three distinct species, Sphingobium indicum sp. nov., Sphingobium japonicum sp. nov. and Sphingobium francense sp. nov., and reclassification of [Sphingomonas] chungbukensis as Sphingobium chungbukense comb. nov. Int J Syst Evol Microbiol 55, 1965-1972.

Pal, R., Bhasin, V. K. \& Lal, R. (2006). Proposal to reclassify [Sphingomonas] xenophaga Stolz et al. 2000 and [Sphingomonas] taejonensis Lee et al. 2001 as Sphingobium xenophagum comb. nov. and Sphingopyxis taejonensis comb. nov., respectively. Int J Syst Evol Microbiol 56, 667-670.

Pinyakong, O., Habe, H. \& Omori, T. (2003). The unique aromatic catabolic genes in sphingomonads degrading polycyclic aromatic hydrocarbons (PAHs). J Gen Appl Microbiol 49, 1-19.
Prakash, O. \& Lal, R. (2006). Description of Sphingobium fuliginis sp. nov., a phenanthrene-degrading bacterium from a fly ash dumping site, and reclassification of Sphingomonas cloacae as Sphingobium cloacae comb. nov. Int J Syst Evol Microbiol 56, 2147-2152.

Riis, V. \& Mai, W. (1988). Gas chromatographic determination of poly$\beta$-hydroxybutyric acid in microbial biomass after hydrochloric acid propanolysis. J Chromatogr 445, 285-289.

Rochelle, P. A., Will, J. A. K., Fry, J. C., Jenkins, G. J. S., Parkes, R. J., Turley, C. M. \& Weightman, A. J. (1995). Extraction and amplification of $16 \mathrm{~S}$ rRNA genes from deep marine sediments and seawater to assess bacterial community diversity. Nucleic Acids in the Environment, pp 219-239. Edited by J. T. Trevors \& J. D. van Elsas. New York: Springer-Verlag.

Singh, A. \& Lal, R. (2009). Sphingobium ummariense sp. nov., a hexachlorocyclohexane $(\mathrm{HCH})$-degrading bacterium, isolated from HCH-contaminated soil. Int J Syst Evol Microbiol 59, 162-166.

Takeuchi, M., Sawada, H., Oyaizu, H. \& Yokota, A. (1994). Phylogenetic evidence for Sphingomonas and Rhizomonas as nonphotosynthetic members of the alpha-4 subclass of the Proteobacteria. Int J Syst Bacteriol 44, 308-314.

Takeuchi, M., Sakane, T., Yanagi, M., Yamasato, K., Hamana, K. \& Yokota, A. (1995). Taxonomic study of bacteria isolated from plants: proposal of Sphingomonas rosa sp. nov., Sphingomonas pruni sp. nov., Sphingomonas asaccharolytica sp. nov. and Sphingomonas mali sp. nov. Int J Syst Bacteriol 45, 334-341.

Takeuchi, M., Hamana, K. \& Hiraishi, A. (2001). Proposal of the genus Sphingomonas sensu stricto and three new genera, Sphingobium, Novosphingobium and Sphingopyxis, on the basis of phylogenetic and chemotaxonomic analyses. Int J Syst Evol Microbiol 51, 1405-1417.

Ushiba, Y., Takahara, Y. \& Ohta, H. (2003). Sphingobium amiense sp. nov., a novel nonylphenol-degrading bacterium isolated from a river sediment. Int J Syst Evol Microbiol 53, 2045-2048.

Wayne, L. G., Brenner, D. J., Colwell, R. R., Grimont, P. A. D., Kandler, O., Krichevsky, M. I., Moore, L. H., Moore, W. E. C., Murray, R. G. E. \& other authors (1987). International Committee on Systematic Bacteriology. Report of the ad hoc committee on reconciliation of approaches to bacterial systematics. Int J Syst Bacteriol 37, 463-464.

Wittich, R.-M., Busse, H.-J., Kämpfer, P., Tiirola, M., Wieser, M., Macedo, A. J. \& Abraham, W.-R. (2007). Sphingobium aromaticiconvertens sp. nov., a xenobiotic-compound-degrading bacterium from polluted river sediment. Int J Syst Evol Microbiol 57, 306-310.

Yabuuchi, E., Yano, I., Oyaizu, H., Hashimoto, Y., Ezaki, T. \& Yamamoto, H. (1990). Proposals of the Sphingomonas paucimobilis gen. nov. and comb. nov., Sphingomonas parapaucimobilis sp. nov., Sphingomonas yanoikuyae sp. nov., Sphingomonas adhaesiva sp. nov., Sphingomonas capsulata comb. nov., and two genospecies of the genus Sphingomonas. Microbiol Immunol 34, 99-119.

Yabuuchi, E., Kosako, Y., Fujiwara, N., Naka, T., Matsunaga, I., Ogura, H. \& Kobayashi, K. (2002). Emendation of the genus Sphingomonas Yabuuchi et al. 1990 and junior objective synonymy of the species of three genera, Sphingobium, Novosphingobium and Sphingopyxis, in conjunction with Blastomonas ursincola. Int J Syst Evol Microbiol 52, 1485-1496.

Young, C. C., Ho, M.-J., Arun, A. B., Chen, W.-M., Lai, W.-A., Shen, F.-T., Rekha, P. D. \& Yassin, A. F. (2007). Sphingobium olei sp. nov., isolated from oil-contaminated soil. Int J Syst Evol Microbiol 57, 26132617.

Young, C.-C., Arun, A. B., Kämpfer, P., Busse, H.-J., Lai, W.-A., Chen, W.-M., Shen, F.-T. \& Rekha, P. D. (2008). Sphingobium rhizovicinum sp. nov., isolated from rhizosphere soil of Fortunella hindsii (Champ. ex Benth.) Swingle. Int J Syst Evol Microbiol 58, 1801-1806. 